Review

\title{
Synergy between Circular Economy and Industry 4.0: A Literature Review
}

\author{
Carlos Andrés Tavera Romero ${ }^{1, * \mathbb{D}}$, Diego F. Castro ${ }^{1}$, Jesús Hamilton Ortiz ${ }^{2}$, Osamah Ibrahim Khalaf ${ }^{3} \mathbb{D}$ \\ and Miguel A. Vargas ${ }^{1}(\mathbb{D}$
}

1 COMBA I+D Research Group of Universidad Santiago de Cali, 760036 Santiago de Cali, Colombia; diego.castro05@usc.edu.co (D.F.C.); miguel.vargas02@usc.edu.co (M.A.V.)

2 Closemobile R\&D Telecommunications LS, 28070 Madrid, Spain; jesushamilton.ortiz@gmail.com

3 Al-Nahrain Nanorenewable Energy Research Center, Al-Nahrain University, Baghdad 10001, Iraq; usama.ibrahem@coie-nahrain.edu.iq

* Correspondence: carlos.tavera00@usc.edu.co; Tel.: +57-311-3348381

Citation: Tavera Romero, C.A.; Castro, D.F.; Ortiz, J.H.; Khalaf, O.I.; Vargas, M.A. Synergy between Circular Economy and Industry 4.0: A Literature Review. Sustainability 2021, 13, 4331. https://doi.org/ $10.3390 /$ su13084331

Academic Editor: Claudio Sassanelli

Received: 26 February 2021

Accepted: 6 April 2021

Published: 13 April 2021

Publisher's Note: MDPI stays neutral with regard to jurisdictional claims in published maps and institutional affiliations.

Copyright: (c) 2021 by the authors. Licensee MDPI, Basel, Switzerland. This article is an open access article distributed under the terms and conditions of the Creative Commons Attribution (CC BY) license (https:// creativecommons.org/licenses/by/ $4.0 /)$.

\begin{abstract}
Recent research has shown that there is a correlation between the circular economy (CE) and Industry 4.0 (I4.0). In addition, other research papers have analyzed the way that CE uses the different I4.0 technologies to transfer from the existing linear economy to CE; however, there are still gaps in the literature regarding the challenges and impacts that society and individuals must face to be ready for the transition from a linear to a circular economy. These challenges seek to guarantee the sustainability and sustainable development of the different business models that mobilize products and services through supply chains. Here, we conducted a review and compilation of the latest bibliography of circular economy and Industry 4.0 theory. The objective of this work is to present the evolutionary relationship between CE and I4.0, as well as its multi-step model of analysis. This research is relevant because its topics are timely and pertinent, especially for academics. Further, at the time that this research was performed, none of the countries were concerned about the impact that technological changes have on the human being and on society, and up to now we do not currently have studies that show how people are being trained to face the transition from the linear economy, which is common in most societies, toward a CE.
\end{abstract}

Keywords: circular economy; Industry 4.0; sustainability

\section{Introduction}

During the industrial revolution, technology was the most important subject. OCDE and circular economy (CE) plans give more relevance to the human component, the relationship between the environment and technology development, and the construction of Society 5.0. The aim of this study was to discuss the role of human society in economic and community progress.

The economic model focused on leveraging resources and reusing waste to create goods and services for mass consumption is currently known as the CE. A CE model seeks to reduce the consumption and emission of resources and waste, with the aim of increasing the useful life of products and services, while, at the same time, becoming eco-friendly and optimizing the energy taken from the different sources available.

This model is based on the same evolution of nature that is currently taking place in the modern world, with a large impact on the use of technologies. Although CE has been documented since the beginning of the 20th century, it is only recently that we find abundant literature assessing its relationship with Industry 4.0 (I4.0).

I4.0 is the fourth industrial revolution, based on the digital transformation adopted by current societies. Some of these societies show evidence that they are heading toward environmental conservation, described as an ecological transition [1]. 
The concepts of CE and I4.0 were born independently; however, they are moving and evolving together, becoming industrial paradigms that, in recent years, have shifted their focus to a restorative industrial production model. The research is in agreement that CE models mostly attempt to design and produce goods and services that reduce waste, supplemented by the implementation of digital technologies that may support their development and are currently framed within the concept of I4.0 [2].

In this context, different studies found in the literature have emphasized the close relationship between sustainability and sustainable development, framed as CE principles and I4.0. Considering I4.0 as an industrial engine and incentive that has increased social awareness of technological effects, decreased the depletion of ecological resources, and driven growing industries toward profitability, there is a strong practice and theoretical relevance in the study of the interconnection among people, technologies, and resources [3].

Other approaches have based their research on logistics and supply chains, assessing case studies and applying different methodologies to reach meaningful conclusions. This is how the authors in [4] developed a literature review with the purpose of identifying the use of service providers known as third party logistics (3PL) in supply chains. These 3PLs provide reverse logistics solutions with an adequate technological infrastructure that provides access to the product and service supply chains by collecting used products for their subsequent transportation, reprocessing, or even redistribution.

In this sense, Rajput and Singh [5] addressed the reduce, reuse, recycle (3R) model used to support the transformation of the supply chain from linear to circular, based on $\mathrm{CE}$ and using emerging technologies (I4.0) as a sustainable and inclusive technological innovation. For its part, in [6], a company was used to verify the application of the framework developed through a hybrid method that proposed using I4.0 and CE as the guiding principles to overcome the challenges faced by supply chains. Few studies have focused on CE and its evolutionary relationship with I4.0 from the human aspect, that is, the social impacts and personal development of human beings linked to the areas of application of these industrial principles of production.

The CE is seen as a model based on the evolution of nature. Therefore, humans must be considered as the main actors since they are always impacted in any change or evolutionary adoption. For this reason, A.M. Gómez, F.A. González, and A. Luque [7] proposed a holonic framework where, through CE and the use of digital and technological I4.0 enablers, the loss of social, economic, and natural resources generated by supply chain growth may be mitigated and reversed. The integrated CE and I4.0 framework allows the supply chain to co-evolve in the environment through adaptation and integration processes oriented toward the mitigation and reversal of metabolic ruptures. By contrast, Kuba and Milichovský [8] sought to establish the relationship between worker age groups, their theoretical conceptualization of I4.0, and the skills and abilities they acquire in their profession. In this study, they aimed to identify the future expectations of technological changes.

This paper is organized as follows: Section 2 conceptualizes both CE and I4.0. Section 3 presents our literature review with its corresponding analysis. In Sections 4 and 5, we discuss the findings and our analysis of the synergy between CE and I4.0. Finally, in Sections 6 and 7, we denote our proposals for future work and our conclusions from this literature review.

\section{Topic Conceptualization}

This review is based on two main notions, the CE and I4.0. In this section, their concepts and definitions are presented.

\subsection{Circular Economy}

The concept of CE became popular on the premise of the economic growth experienced by China in the 1990s and the limited natural resources available to produce goods and services. The studies that were conducted at that time on CE concluded that manufacturing systems were lacking in social aspects and sustainability. There is currently a lack of 
clarity in the justification of how CE may fulfill the three pillars of sustainability from a social perspective [5]. A good definition of CE has been provided by the Ellen MacArthur Foundation, which defines $\mathrm{CE}$ as a "restorative and regenerative system by design," whose purpose is to keep products, components, and materials at their maximum usefulness and value [9].

For their part, Rajput and Singh [5] stated that CE is configured as a closed supply chain that seeks restorative and regenerative use, which implies that the system is conceptualized within the "end-of-life" or "lifespan" of the products and services at an industrial level, thus eliminating toxic materials, and reusing and eliminating waste through the explicit implementation of design models, product systems, and materials design. In terms of the supply chain, the purpose of $\mathrm{CE}$ is to make resources more efficient and optimize environmental results. In addition, $\mathrm{CE}$ is known for using an economic model aimed at minimizing the consumption of materials to instead focus on their intelligent use. CE models transition from a classical open linear economic model to a closed circular model, centered on providing positive and balanced economic, environmental, and social impacts [2].

The organizational transition to CE is progressing, denoting that there is still a gap between the linear and circular models. Linear economic models find their accent on the remaining linear supply chains, wherein raw materials continue to be wasted [6]. Studies addressing the factors linked to linear economies have indicated that they are unsustainable and demonstrate the urgent need for adopting a new paradigm-shifting model that can foster the necessary transition towards a CE [5].

\subsection{Industry 4.0}

I4.0, also known as the technological revolution, encompasses big data, industrial automation (robotics), simulations, integration systems, the internet of things (IoT), cybersecurity, cloud computing, additive manufacturing, and augmented reality as the main comprehensive factors of technological work aimed at continuous improvement. As a concept, I4.0 combines information and communication technologies (ICTs) with production and manufacturing processes [10]. Figure 1 provides an overview of how I4.0 integrates major technologies, and the pillars of I4.0 are outlined following.

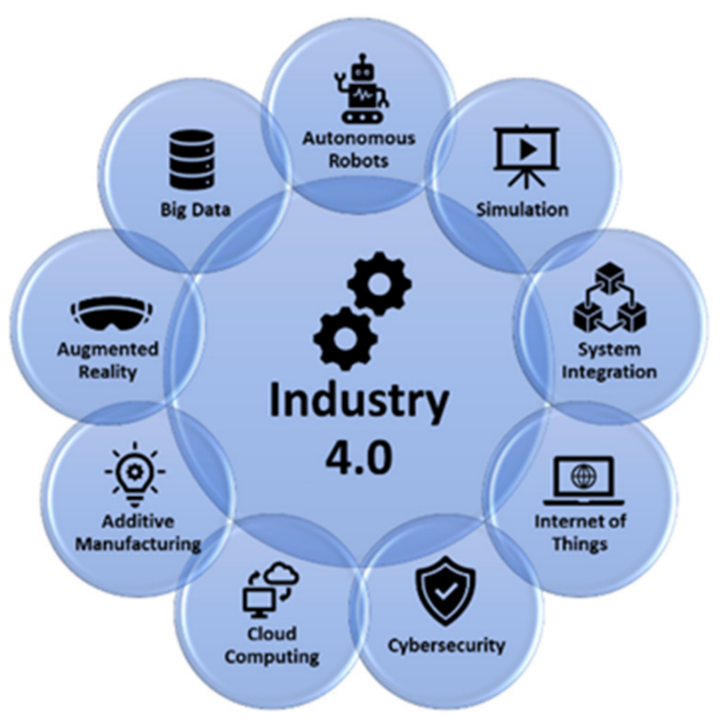

Figure 1. Technological integration in Industry 4.0. 


\subsubsection{Big Data}

Big data is a set of technological tools created with the capacity to capture, store, manage, process, and analyze a large variety and high volumes of data. Big data was created because conventional tools failed to perform these tasks in viable timeframes [5], and it supports product development processes, supply and demand, production logistics, communications, radio frequency (RFID), and product identification (sensors and barcodes), and so on, through IoT implementation [10].

\subsubsection{Industrial Automation (Robotics)}

Industrial automation refers to incorporating artificial intelligence (AI) into software. It possesses machine learning capabilities for systematically performing repetitive tasks, previously performed by humans, on a large scale.

\subsubsection{Simulations}

Simulations are used to model systems extracted from the real environment to assess their behavior under different conditions and understand their responses to different direct and indirect agents that may influence the system results [11]. Due to their flexibility, simulations are a fundamental pillar in I4.0, as they may be implemented in any field, such as manufacturing, services, design, and healthcare. I4.0 finds software-based process simulation beneficial by virtue of the implementation of analytical processes.

\subsubsection{Integration Systems}

This concept refers to linking system components (vertical integration) or two or more systems (horizontal integration) to provide the interfaces required to associate physical and virtual system objects. It is also known as end-to-end integration.

\subsubsection{Internet of Things (IoT)}

First defined in 1999 by Kevin Ashton, the IoT is conceived as a system that transfers products, service, process, activity, or task data in real time, thus supporting dynamic information management [12]. On the other hand, Lopez de Sousa et al. [10] defined IoT as the interconnection between electronic systems that exchange and collect data in real time, generating added value to the final object.

\subsubsection{Cybersecurity}

Cybersecurity helps organizations create secure business controls, as well as the methods used to assess those controls, to improve the effectiveness of industrial systems. Cybersecurity means using intelligent interconnected cyber-physical systems to automate industrial operations through secure networks, and providing security protocols that offer protection against cyber threats.

\subsubsection{Cloud Computing}

Cloud computing is a digital infrastructure that facilitates access through the internet to computing and processing engines located in remote servers. Currently, the use of cloud computing has been promoted to implement electronic commerce services, facilitating the interaction between customers and vendors characterized by resource virtualization and the automation of logistics and business processes [10].

\subsubsection{Additive Manufacturing (3D)}

Additive manufacturing is based on the generation of product parts without having to acquire and use specialized tools while reducing waste, thus differentiating manufacturing from conventional processes. Production is based on three-dimensional (3D) digital designs, using conventional raw materials without the requirement of preconceived molds [13]. 3D printers are the main resources associated with additive manufacturing. 


\subsubsection{Augmented Reality (AR) and Virtual Reality (VR)}

Augmented reality (AR) is a technology used by I4.0 as an approach in which people use digital tools to access virtual spaces superimposed on actual physical spaces through virtual information data. AR is positioned between the physical world and virtual reality (VR), without replacing the real world, but allowing data to be collected from simulations in order to better understand real-world systems.

\section{Literature Search and Selection Procedure and Criteria}

The criteria used for searching and selecting papers, as well as the implicit process developed for these purposes, are described below. As reference, we used Snyder's [14] "Literature Review as a Research Methodology: General Description and Guidelines". The research question for this study was: "How has the synergy between I4.0 and CE impacted societies in the last 3 years?" The main steps performed for finding and selecting academic papers for review are described below.

\subsection{Search Criteria}

To guarantee suitable content and approach transparency, only certain specific databases were considered. The search criteria defined for the research question were "circular economy and Industry 4.0", "sustainability and circular economy", and "circular economy and society".

During the review, only formal literature (scientific publications, academic papers, industrial case studies, and conference proceedings) was considered. The queries were made in the following international databases: IEEE, Scopus, and ScienceDirect. The search was conducted considering only documents written in English and published between 2018 and 2020.

The total process was carried out in four steps. First, in the identification stage, we began with 4484 papers based on the above search criteria. After removing duplicate papers, we had 2261 remaining. In the screening stage, we only selected papers from the last three years, which reduced the number to 1884 . In the eligibility stage, we filtered by the paper structure, citations, methodology, and internationalism, and the result was 179 papers. After that, we made other selections by the main topic "industry and economy", and the number of papers became 124. In the end, after selection of the papers by the subjects $\mathrm{CE}$ and I4.0, there were 41 papers.

\subsection{Search Strategy}

Through the advanced search of the consulted databases, three search strings were considered to collect documents for subsequent review. We used Boolean operators, such as AND, OR, and NOT, in these search strings. Three databases were used to search and filter the relevant papers: Science Direct, IEEE, and Wiley Interscience. Figure 2 illustrates the search process.

\subsection{Content Analysis}

The results of the search conducted in terms of the number of papers published per semester are shown in Figure 3. A total of 41 papers were reviewed, of which 95\% focused on the main topic of the study. If scientific journals with an assessment indicator of relative importance are considered (Ranking Q1 in Scimago), we found that 83\% of the journals were categorized and interested in publishing these topics. Figure 4 shows the main journals dedicated to the publication of the topics discussed in this paper. 


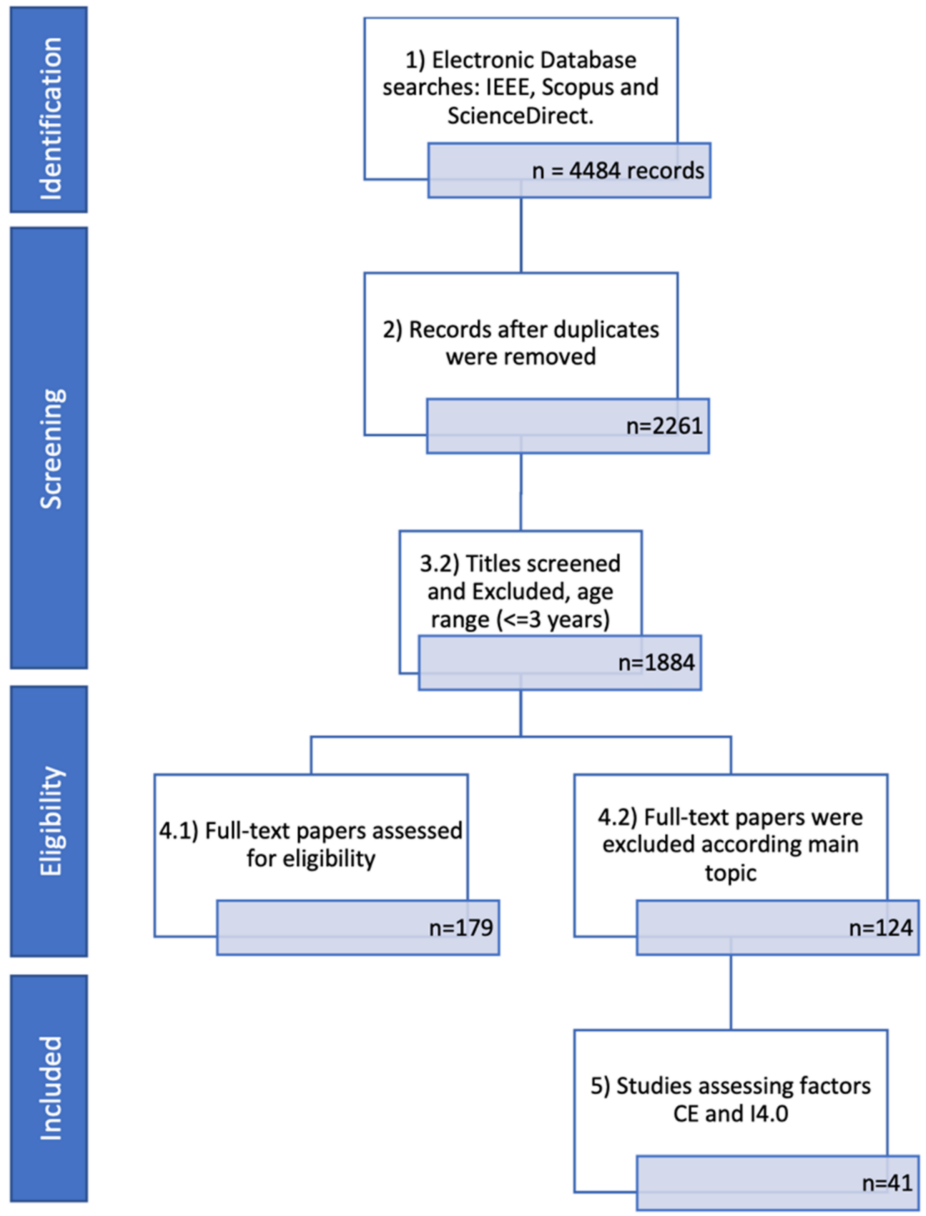

Figure 2. Search process.

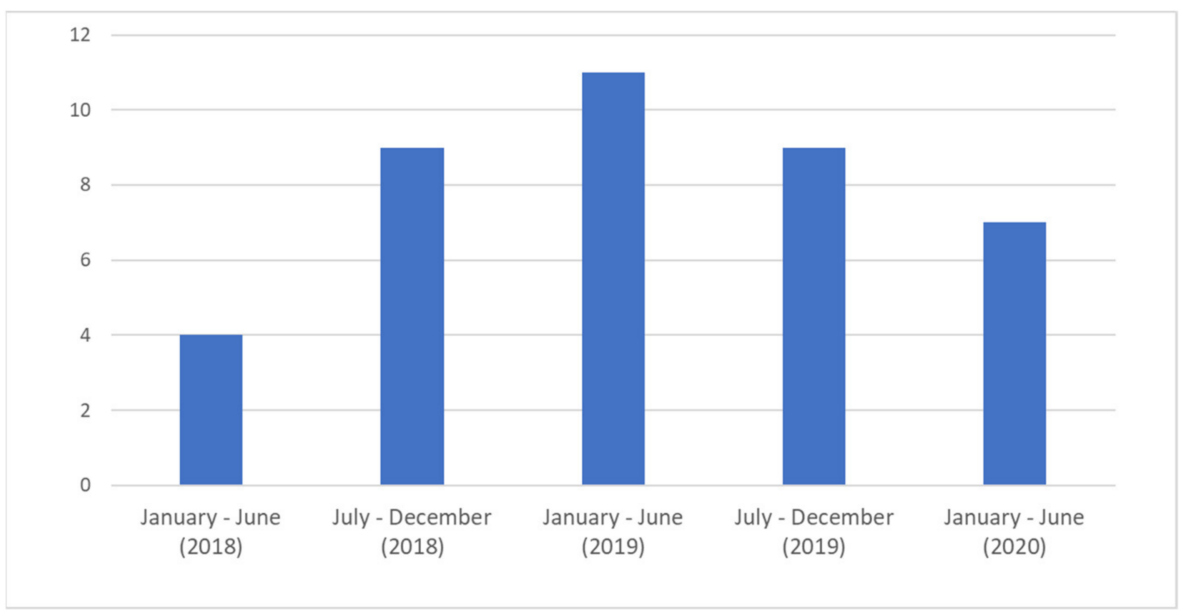

Figure 3. Historical series of published papers. 


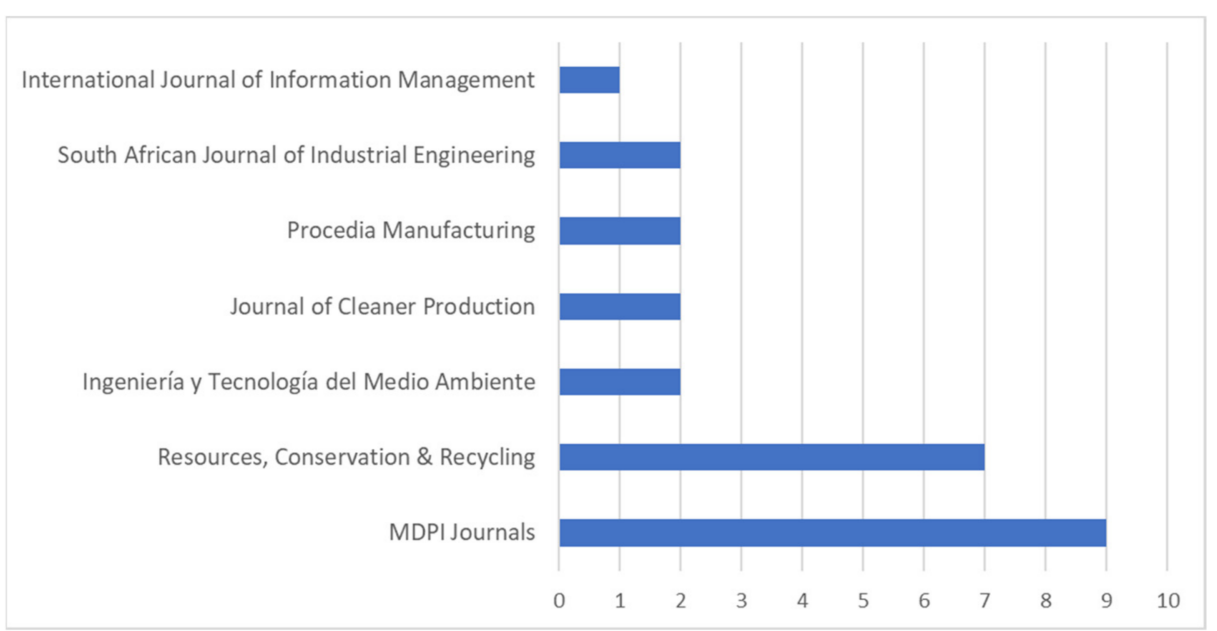

Figure 4. Main scientific journals.

Twelve percent of all papers reviewed were published in the form of conference proceedings. Regarding the countries in which the authors' affiliation institutions are located, Figure 5 highlights India, Italy, Spain, Brazil, and the United Kingdom, accounting for $54 \%$ of the total number of published works. Figure 6 lists the topics and their classification by group of published papers, wherein the influence from I4.0 influences and its different technological applications within the context of $\mathrm{CE}$ and sustainability were considered as the first selection criterion. The multidisciplinary factor was the main supporting aspect of the research analysis.

$\mathrm{CE}$ and I4.0 are topics that have been highly explored in recent years. The publication trends on research topics revolving around CE and I4.0 showed an increase toward 2020. Our analysis also considered the methodologies used by the authors, whether the case studies were taken from real activities, the transition toward the $\mathrm{CE}$, and the correlation between $\mathrm{CE}$ and I4.0.

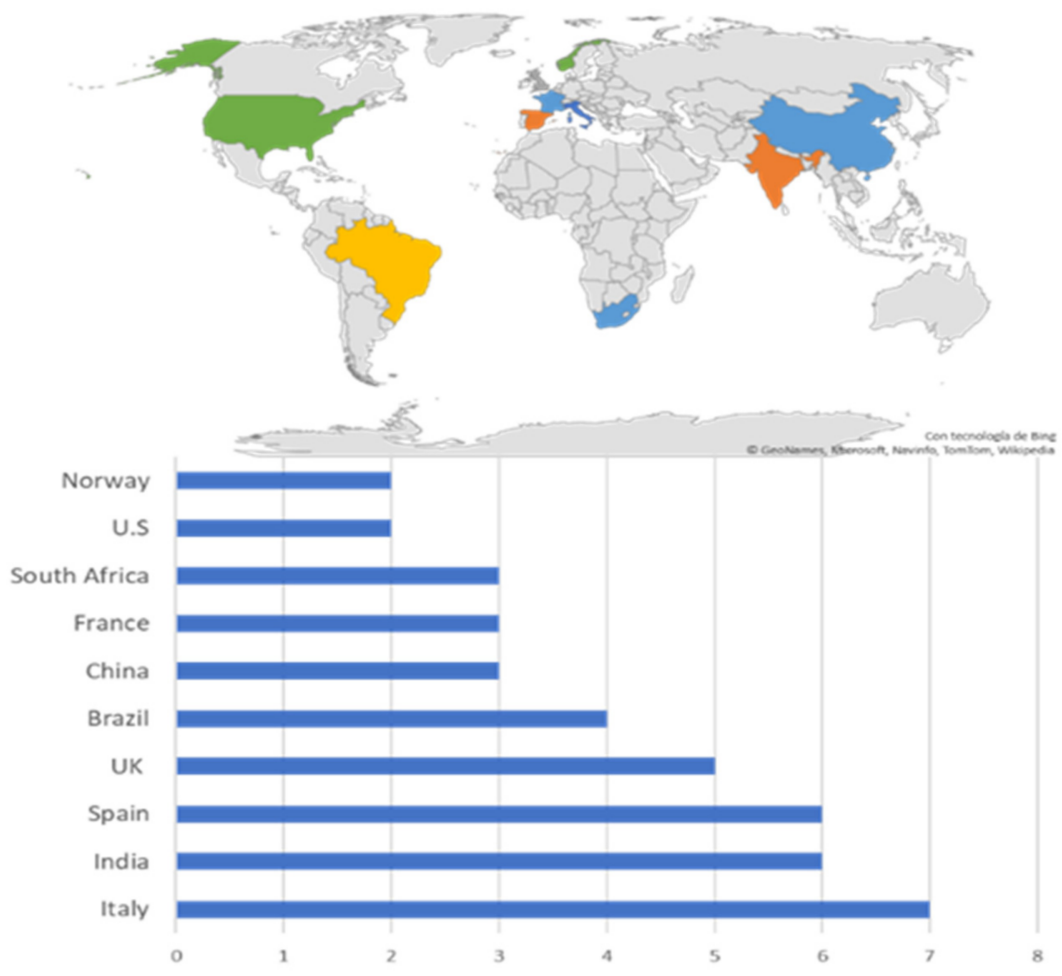

Figure 5. Main publishing countries. 


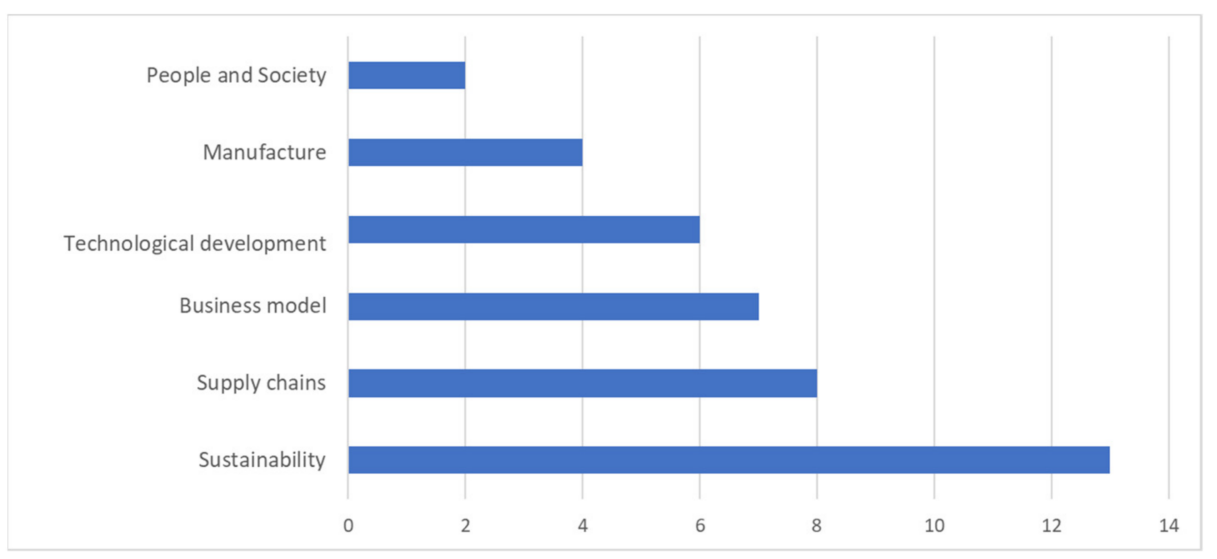

Figure 6. Topics classified by group of papers.

In terms of methodology, most authors developed their research through case studies and literature reviews. In their papers, many of the authors addressed the binding relationship between CE and I4.0, highlighting the latter as the main protagonist with the application of its technological phases in the transition that organizations and their supply chains must undertake to evolve from a linear to a circular economy.

For the review of the selected research papers, we also identified and systematized the most relevant aspects found in the results, discussions, and conclusions of the papers selected for this literature review. Each of the main topics of the reviewed publications was identified and coded (see Table 1), and the I4.0 technologies referenced by each publication were also considered.

Table 1. Topics and abbreviations.

\begin{tabular}{ccc}
\hline Central Topic & Main Topic & Abbreviation \\
\hline & Supply chain management & SCM \\
& Technological development & TD \\
Manufacturing & MAN \\
& Business model & BM \\
& Sustainability & SUS \\
& People and society & PS \\
\hline & Big data & BD \\
& Industrial automation (robotics) & IA \\
& Simulation & SIM \\
& Integration systems & IOT \\
& Internet of things (IoT) & CYB \\
& Cybersecurity & CC \\
& Cloud computing & AM \\
& Additive manufacturing (3D) & AR \\
\hline
\end{tabular}

\section{Results}

The information of the selected papers is presented in a table, including the main topic, reference number, type, and objective. Subsequently, the relevant data were extracted after a detailed reading, grouping different publications according to their common topic, as shown in Table 2. 
Table 2. Classification of publications.

\begin{tabular}{|c|c|c|c|}
\hline Main Topic & Reference & Type & Objective \\
\hline \multirow{8}{*}{ Supply Chain } & [4] & Review & $\begin{array}{c}\text { Literature systematic review on 3PLS operators in } \\
\text { reverse logistics. }\end{array}$ \\
\hline & [7] & Framework & $\begin{array}{l}\text { Proposal for a holonic multiscale framework for integrated } \\
\text { sustainable supply chain management that allows evolution } \\
\text { taking environment into account. }\end{array}$ \\
\hline & [15] & Framework & $\begin{array}{l}\text { Proposes the thematic framework that must be considered in } \\
\text { research studies seeking to address the opportunities and } \\
\text { challenges that the I4.0 supply chain must face in CE } \\
\text { environments. }\end{array}$ \\
\hline & [16] & Case study & $\begin{array}{l}\text { Analysis of the supply chain of an organization to meet the } \\
\text { requirements of Industry } 4.0 \text { and enable the circular economy, } \\
\text { based on the concept of } 6 \text { Rs. }\end{array}$ \\
\hline & [17] & Framework & $\begin{array}{l}\text { Analysis of the sustainable supply chain in the health sector to } \\
\text { propose the conceptual framework for the transition of the } \\
\text { circular economy. }\end{array}$ \\
\hline & [18] & Mathematical model & $\begin{array}{l}\text { This paper proposes a route for reverse logistics in a sustainable } \\
\text { reverse supply chain by implementing the principles of I4.0 and } \\
\text { the ReSOLVE model of circular economy (CE). }\end{array}$ \\
\hline & [5] & Review & $\begin{array}{l}\text { Understanding the hidden connection between the circular } \\
\text { economy }(\mathrm{CE}) \text { and Industry } 4.0 \text { in the context of the supply chain. }\end{array}$ \\
\hline & [6] & Framework & $\begin{array}{l}\text { This paper proposes a solution framework supported in I4.0 and } \\
\text { CE to overcome the challenges of supply chain } 4.0 \text { and the } \\
\text { circular economy. }\end{array}$ \\
\hline \multirow{5}{*}{ Technological Development } & [19] & Review & $\begin{array}{l}\text { This paper proposes an integrative framework for the } \\
\text { formulation of policies for future research through a systematic } \\
\text { review of literature in terms of CE and I4.0 fields. }\end{array}$ \\
\hline & [20] & Case study & $\begin{array}{l}\text { An assessment of a management model for the analysis capacity } \\
\text { of Industry } 4.0 \text { technologies based on different costing models } \\
\text { (ABC and TDABC). }\end{array}$ \\
\hline & [21] & Review & $\begin{array}{l}\text { This paper presents a results summary of project } \mathrm{K} \text {, recycling and } \\
\text { waste recovery } 4.0 \text { publications, considering the systems, } \\
\text { methods and technologies used in the industry and } \\
\text { waste collection. }\end{array}$ \\
\hline & [11] & Case study & $\begin{array}{l}\text { This paper presents a lab showing how I4.0-based technologies } \\
\text { can support CE practices through virtual testing. }\end{array}$ \\
\hline & [22] & Case study & $\begin{array}{l}\text { An assessment of differences and similarities in the } \\
\text { implementation of big data in the cryptocurrency sector and } \\
\text { municipal waste management. }\end{array}$ \\
\hline \multirow{4}{*}{ Manufacturing } & [23] & Case study & $\begin{array}{l}\text { This paper defines an approach to product design based on user } \\
\text { experience considering smart production as the foundation of } \\
\text { I4.0 in the circular economy of the glass recycling industry. }\end{array}$ \\
\hline & [24] & Case study & $\begin{array}{l}\text { This paper implements tools to define the balance point between } \\
\text { sustainability and the circular economy in the environment for } \\
\text { the manufacturing of ceramic tiles, and demonstrates how new } \\
\text { business opportunities can be created through the evolution of a } \\
\text { linear business model toward a circular model, thanks to I4.0. }\end{array}$ \\
\hline & [25] & Framework & $\begin{array}{c}\text { This paper examines the technical limitations of implementing } \\
\text { zero-waste manufacturing technologies ZWM in dense urban } \\
\text { areas in Singapore. }\end{array}$ \\
\hline & [26] & Framework & $\begin{array}{l}\text { An assessment of circular economy implementation in electrical } \\
\text { and electronic equipment production, considering the waste } \\
\text { amount generated, as well as raw materials and the } \\
\text { energy balance. }\end{array}$ \\
\hline
\end{tabular}


Table 2. Cont.

\begin{tabular}{|c|c|c|c|}
\hline Main Topic & Reference & Type & Objective \\
\hline \multirow{7}{*}{ Business Model } & [10] & Framework & $\begin{array}{l}\text { This paper assesses how I4.0 can support CE strategies, providing } \\
\text { bases for decision-making in sustainable operations management. }\end{array}$ \\
\hline & [13] & Framework & $\begin{array}{l}\text { This paper assesses how I4.0 integrates with the circular economy } \\
\text { (CE) to establish a business model that reuses and recycles waste } \\
\text { such as scrap metal or electronic waste. }\end{array}$ \\
\hline & [9] & Framework & $\begin{array}{c}\text { This paper develops a conceptual framework, based on literature } \\
\text { and a case study of a company, identifying the functionalities of } \\
\text { I4.0 that implement a business model focused on the use of the } \\
\text { industrial household appliance. }\end{array}$ \\
\hline & [27] & Case study & $\begin{array}{l}\text { This paper explores how I4.0 integrates with the circular } \\
\text { economy (CE) to establish a business model that reuses and } \\
\text { recycles waste such as scrap metal or electronic waste. }\end{array}$ \\
\hline & [2] & Framework & $\begin{array}{l}\text { This paper develops an innovative framework that highlights the } \\
\text { links between I4.0 and CE and the unveiling of future fields } \\
\text { of research. }\end{array}$ \\
\hline & [28] & Framework & $\begin{array}{l}\text { This paper identifies how purchases } 4.0 \text { and digital } \\
\text { transformations are related, in addition to how digital } \\
\text { transformation impacts the intention to optimize the hiring } \\
\text { process in the circular economy. }\end{array}$ \\
\hline & [29] & Case study & $\begin{array}{l}\text { This paper addresses challenges and opportunities for the } \\
\text { collaborative economy based on original evidence compiled from } \\
\text { cases of the Brazilian manufacturing industry that use natural } \\
\text { metallic resources. }\end{array}$ \\
\hline \multirow{11}{*}{ Sustainability } & [30] & Framework & $\begin{array}{c}\text { This paper presents the existing gaps between data and } \\
\text { sustainability as the optimal solution for the existence of an } \\
\text { industrial symbiosis. }\end{array}$ \\
\hline & [12] & Framework & $\begin{array}{l}\text { This paper proposes reducing or eliminating the source of } \\
\text { impacts to create environmental value through the sustainability } \\
\text { of a global ecosystem. }\end{array}$ \\
\hline & [31] & Framework & $\begin{array}{l}\text { This paper evaluates sustainability in smart products connected } \\
\text { to each other, through methodological development oriented } \\
\text { to I4.0. }\end{array}$ \\
\hline & [32] & Case study & $\begin{array}{l}\text { This paper describes a mobile equipment model with the ability } \\
\text { to provide sustainability to conventional videographic } \\
\text { production equipment by applying CE principles. }\end{array}$ \\
\hline & [33] & Case study & $\begin{array}{l}\text { This paper explores the transition from linear economy to circular } \\
\text { economy through a procedure to introduce the sustainability } \\
\text { principles (environmental, economic, and social). }\end{array}$ \\
\hline & [34] & Framework & $\begin{array}{l}\text { This paper addresses the concept of sustainable development and } \\
\text { the need for its introduction in the circular economy activity. }\end{array}$ \\
\hline & [35] & Case study & $\begin{array}{l}\text { This paper exemplifies a model taken from the literature that } \\
\text { considers automobile manufacturing and shows how we can deal } \\
\text { with the problem using standard techniques of performance } \\
\text { evaluation in the circular economy. }\end{array}$ \\
\hline & [1] & Case study & $\begin{array}{c}\text { This paper evaluates the sustainability of agri-food processes and } \\
\text { their environmental impacts using big data technologies to } \\
\text { improve management in the supply chain. }\end{array}$ \\
\hline & [36] & Review & $\begin{array}{l}\text { Literature review on emerging digital technologies from I4.0 } \\
\text { focused on sustainability through remanufacturing. }\end{array}$ \\
\hline & [37] & Mathematical model & $\begin{array}{l}\text { This paper investigates the relationship of economic } \\
\text { development measured as economic growth, energy use, trade } \\
\text { and foreign direct investment, and the environment in eleven } \\
\text { emerging countries in Eastern Europe and Asia. }\end{array}$ \\
\hline & [38] & Case study & $\begin{array}{l}\text { This paper explores the feasibility of a redistributed business } \\
\text { model for manufacturers employing new manufacturing } \\
\text { technologies (I4.0) as part of a sustainable and circular } \\
\text { production and consumption system. }\end{array}$ \\
\hline
\end{tabular}


Table 2. Cont.

\begin{tabular}{|c|c|c|c|}
\hline Main Topic & Reference & Type & Objective \\
\hline \multirow[b]{2}{*}{ Sustainability } & [39] & Framework & $\begin{array}{l}\text { This paper presents a scheme of risks in the Industry } 4.0 \text { situation } \\
\text { that is associated to the triple bottom line of sustainability. }\end{array}$ \\
\hline & [3] & Review & $\begin{array}{l}\text { An assessment of the literature that jointly considers the concepts } \\
\text { of sustainability, sustainable development, and sociotechnics, as } \\
\text { well as their transitions with I4.0. }\end{array}$ \\
\hline \multirow{3}{*}{ People and Society } & [40] & Framework & $\begin{array}{c}\text { This paper examines the role of CE in addressing COVID-19 by } \\
\text { relating issues both in the present and in the future using } \\
\text { strategies to close, reduce, and slow resource loops as a life } \\
\text { sustainability strategy. }\end{array}$ \\
\hline & [41] & Framework & $\begin{array}{l}\text { An assessment of the relationship between happiness, co-creation, } \\
\text { and sustainable development as a theoretical framework based } \\
\text { on the well-established construct of value co-creation. }\end{array}$ \\
\hline & [8] & Case study & $\begin{array}{l}\text { This paper aims to discover the possible relationships between } \\
\text { the age of workers and knowledge of the concept of Industry 4.0, } \\
\text { the threats of new technologies, and the future expectation of } \\
\text { technological changes. }\end{array}$ \\
\hline
\end{tabular}

The literature review of the papers selected allowed us to establish a reciprocal relationship between CE and I4.0 - in other words, to describe the way I4.0 and its technologies exerted a direct effect on $\mathrm{CE}$, or vice versa, and how $\mathrm{CE}$ and its different applications promoted the functionality of I4.0 technologies. The studies that have been published to date show a wide range of technological applications to the various contexts of organizations and their manufacturing and marketing processes through supply chains. Out of the 41 papers found in the searched databases that were directly related to the topic at hand and, therefore, selected for our literature review, 32.5\% (13) were published in 2018, 50\% (20) were published in 2019, and the remaining $17.5 \%$ (7) in 2020.

The papers analyzed in this review were classified by type, as shown Figure 7 . These papers focused mostly on presenting frameworks, and few of them focused on mathematical models. A total of $35 \%$ of the reviewed papers were study cases applied to frameworks proposed in previous years; however, $45 \%$ of the research presented frameworks that proposed potential study cases for future works. Only $15 \%$ of the papers were reviews, which suggests developing more reviews for works published in recent years.

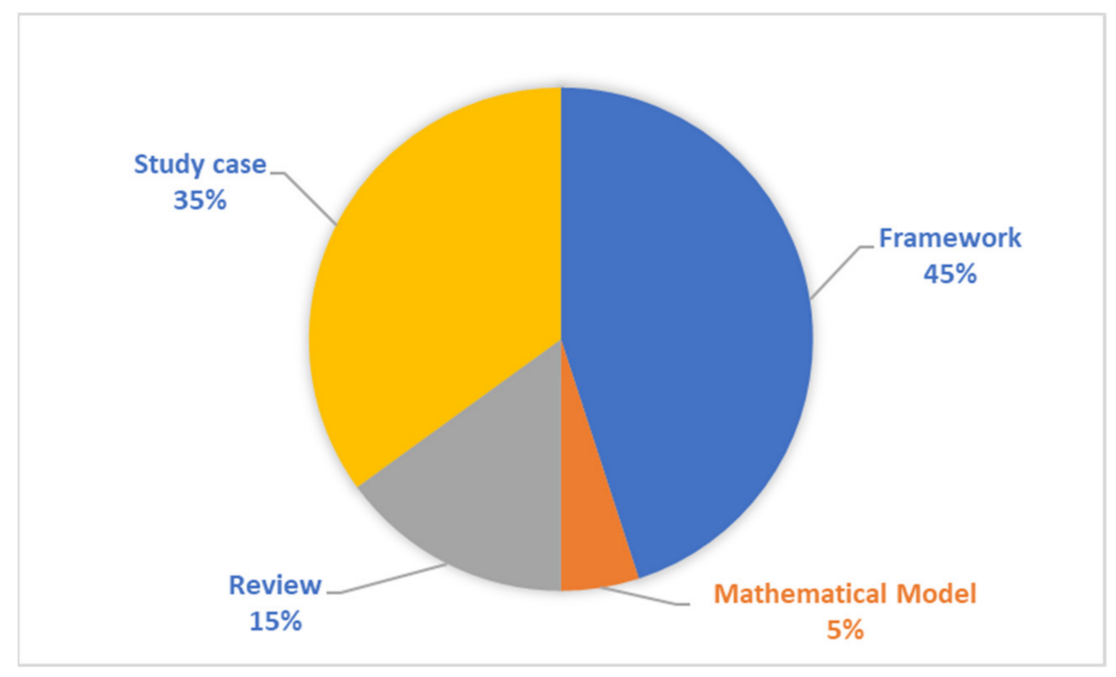

Figure 7. Classification of papers.

The 10 countries with the highest concentration of publications, in which $77 \%$ of the reviewed publications were found, are shown in Figure 8. Figure 8 shows the thematic 
preferences developed by the top 10 countries as identified and classified in the group of reviewed papers.

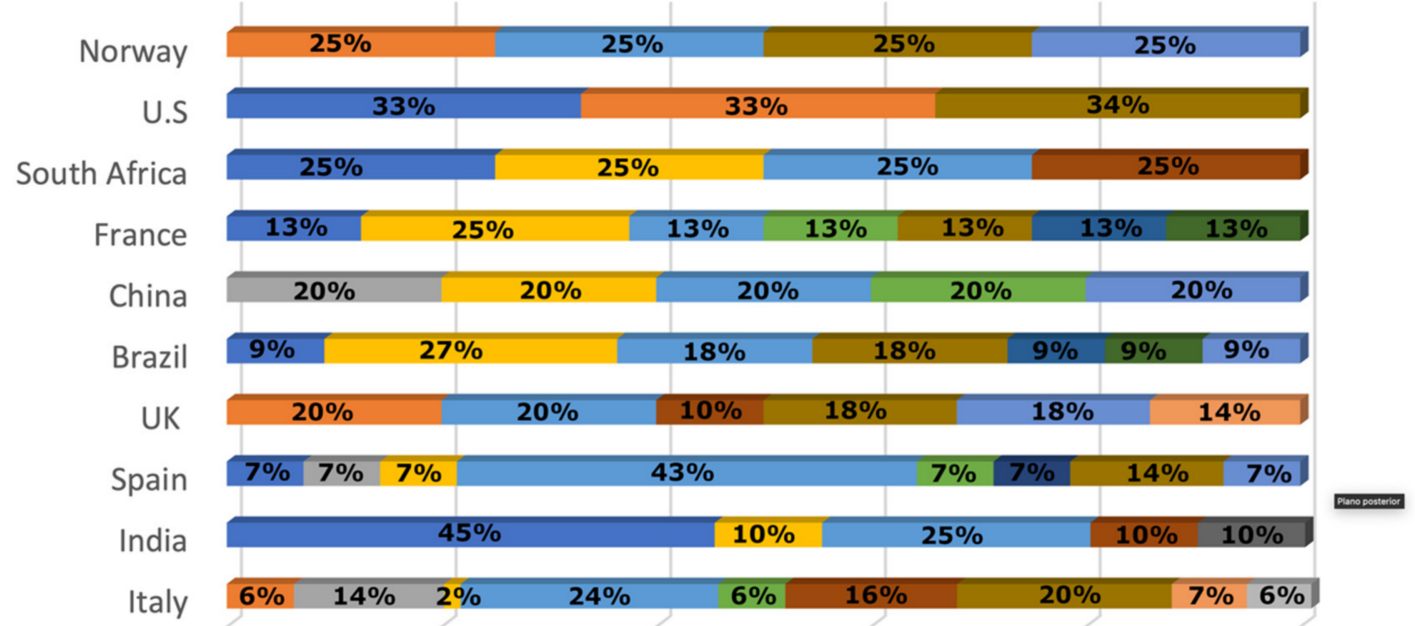

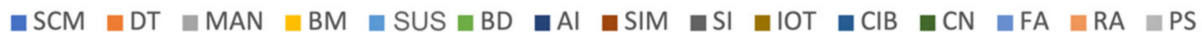

Figure 8. Development topic by country.

In this review, all papers focused their research on CE through sustainability and technological applications of I4.0. The top three topics related to CE were sustainability (SUS), with 23 papers; supply chain management (SCM), with 10 papers; and business models (BM), with 11 papers. Except the US, all countries had related papers on SUS with percentages in the range of $13 \%$ to $43 \%$, for example Spain. India, the US, and South Africa led in the percentages of papers developing topics on SCM, at $25 \%$ to $45 \%$ of their total studies. Finally, Brazil, South Africa, and France showed much higher percentages of papers on $\mathrm{BM}$, from $25 \%$ to $27 \%$. On the other hand, the top topic related to I4.0 was IOT, with 17 papers. Other I4.0 topics had fewer related papers. This shows that the studies had specific approaches to CE, while they selected a more varied set of tools for I4.0.

Regarding the subject of people and society (PS), we identified that $[8,40,41]$ are some of the recent research works dedicated to understanding how CE directly impacts individuals and how they should prepare to face the changes required by on-going transition from linear to circular economic models. Table 3 shows the relationship between the topics identified and categorized for each one of the different selected research studies, which highlight SCM, technological development (TD), manufacturing (MAN), SUS, and PS as the main topics of CE. In turn, these issues are contrasted against the technologies envisioned in I4.0 to identify the relationship between CE and I4.0 described in each paper.

The analysis demonstrated that CE is mainly supported by SUS, SCM, and MAN using IOT and big data (BD) as the main I4.0 technologies to propose a linear-to-circular model transition that may support sustainability or sustainable economic development. In their literature review, Rosa et al. [2] summarized that papers addressing the relationship between CE and I4.0 should be viewed in a generic way. Herein, the authors also claimed that any organization undergoing a transition from a linear to a circular economy must implement technological development within its value chain through I4.0.

In their literature review, Okorie et al. [19] mentioned a growing trend in CE and I4.0 publications when considering areas of individual research, especially during the 2012-2018 period. At the time, the US and China led the research, in terms of engineering and informatics. In addition, Kerin and Pham [36], based on their own literature review, also viewed the IOT and AR as necessary technologies for manufacturing. 
Table 3. Relationship between CE and I4.0.

\begin{tabular}{|c|c|c|c|c|c|c|c|c|c|c|c|c|c|c|c|}
\hline \multirow[b]{2}{*}{ Reference } & \multicolumn{6}{|c|}{ Circular Economy } & \multicolumn{9}{|c|}{ Industry 4.0} \\
\hline & SCM & TD & MAN & BM & SUS & PS & BD & IA & SIM & IS & IOT & CYB & $\mathrm{CC}$ & AF & AR \\
\hline [1] & $x$ & & & & $x$ & & $x$ & & & & & & & & \\
\hline [2] & & & & $x$ & & & & & & & $x$ & & & & \\
\hline [3] & & & & & $x$ & & & & & & & & & & \\
\hline [4] & $x$ & & & & & & & & & & $x$ & & & & \\
\hline [5] & $x$ & & & & & & & & & $x$ & & & & & \\
\hline [6] & $x$ & & & & $x$ & & & & & & & & & & \\
\hline [7] & $x$ & & & & $x$ & & & & & & & & & & \\
\hline [8] & & $x$ & & & & & & & & & $x$ & & & $x$ & \\
\hline [9] & & & & $x$ & & & $x$ & & & & $x$ & & & & \\
\hline [10] & & & & $x$ & & & & & & & $x$ & $x$ & $x$ & & \\
\hline [11] & & $x$ & & & & & & & $x$ & & & & & & $x$ \\
\hline [12] & & & & & $x$ & & & & & & $x$ & & & & \\
\hline [13] & & & & $x$ & $x$ & & & & & & & & & $x$ & \\
\hline [15] & $x$ & & & & & & & & & & $x$ & & & & \\
\hline [16] & $x$ & & & & $x$ & & & & & & & & & & \\
\hline [17] & $x$ & & & & $x$ & & & & & & $x$ & & & & \\
\hline [18] & $x$ & & & & $x$ & & & & & & & & & & \\
\hline [19] & & $x$ & & & & & & & & & $x$ & & & & \\
\hline [20] & & $x$ & & & & & & & & & & & & & \\
\hline [21] & & $x$ & & & & & & $x$ & & & & & & & \\
\hline [22] & & $x$ & & & & & $x$ & & & & & & & & \\
\hline [23] & & & $x$ & & & & & & & & & & & $x$ & \\
\hline [24] & & $x$ & & $x$ & & & & & & $x$ & & & & & \\
\hline [25] & & & $x$ & & & & & & & & $x$ & & & & \\
\hline [26] & & & $x$ & & & & $x$ & & & & $x$ & & & & \\
\hline [27] & & & & $x$ & & & & & & & & & & & \\
\hline [28] & & & & $X$ & & & & & $x$ & & & & & & \\
\hline [29] & & & & $X$ & & & $x$ & & & & & & & & \\
\hline [30] & & & & & $x$ & & $x$ & & & & & & & & \\
\hline [31] & & & & & $x$ & & $x$ & $x$ & & & & & & & \\
\hline [32] & & & & & $x$ & & & & & & & & & $x$ & \\
\hline [33] & & & & $x$ & $x$ & & & & & & $x$ & & & & \\
\hline [34] & $x$ & & & & $x$ & & & & & & & & & & \\
\hline [35] & & & $x$ & & $x$ & & & & & & & & & & \\
\hline [36] & & & & $X$ & $x$ & & & & & & $x$ & & & & $x$ \\
\hline [37] & & & & & $x$ & & & & & & $x$ & & & $x$ & \\
\hline [38] & & & & $x$ & $x$ & & & & & & & & & $X$ & \\
\hline [39] & & $x$ & & & $x$ & & & & & & $x$ & & & $X$ & \\
\hline [40] & $x$ & & & & $x$ & $x$ & & & & & & & & & \\
\hline [41] & & & & & $x$ & $x$ & & & & & & & & & \\
\hline Total & 11 & 7 & 5 & 10 & 23 & 2 & 8 & 4 & 3 & 2 & 17 & 2 & 2 & 8 & 3 \\
\hline
\end{tabular}




\subsection{Contributions per Journal}

Table 4 displays information on the total number of papers published in scientific journals, detailing the percentages for each journal with respect to the total of 41 publications that were reviewed. The MDPI journals and Resources, Conservation \& Recycling journal accounted for $34.88 \%$ of the papers reviewed. The other 23 journals, wherein one or two papers were published, provided $35.12 \%$ of the papers reviewed.

Table 4. Contributions per journal.

\begin{tabular}{|c|c|c|}
\hline Journal Title & Publications No. & $\%$ \\
\hline MDPI journals & 8 & 18.60 \\
\hline Resources, Conservation $\mathcal{E}$ Recycling & 7 & 16.28 \\
\hline Ingeniería y Tecnología del Medio Ambiente & 2 & 4.65 \\
\hline International Journal of Information Management & 2 & 4.65 \\
\hline Journal of Cleaner Production & 2 & 4.65 \\
\hline Procedia Manufacturing & 2 & 4.65 \\
\hline South African Journal of Industrial Engineering & 2 & 4.65 \\
\hline 19th International Multidisciplinary Scientific GeoConference & 1 & 2.33 \\
\hline Computers $\mathcal{E}$ Industrial Engineering & 1 & 2.33 \\
\hline Computers in Industry & 1 & 2.33 \\
\hline CrossMark & 1 & 2.33 \\
\hline Economics of Food Industry & 1 & 2.33 \\
\hline International Journal of Production Research & 1 & 2.33 \\
\hline Journal of Business Research & 1 & 2.33 \\
\hline Journal of Engineering & 1 & 2.33 \\
\hline Journal of Manufacturing Technology Management & 1 & 2.33 \\
\hline Journal Risk and Financial Management & 1 & 2.33 \\
\hline Littera Scripta & 1 & 2.33 \\
\hline MobileHCI-2018 & 1 & 2.33 \\
\hline Plastics Technology & 1 & 2.33 \\
\hline Resources Policy & 1 & 2.33 \\
\hline Socio-Economic Planning Sciences & 1 & 2.33 \\
\hline Trakia Journal of Sciences & 1 & 2.33 \\
\hline ValueTools '20 & 1 & 2.33 \\
\hline Waste Management & 1 & 2.33 \\
\hline
\end{tabular}

\subsection{Contributions per Country}

There were 22 countries considered in the analysis, which we associated to the nationality of the authors of the research papers reviewed. According to Table 5, the top five countries were Italy, India, Spain, the United Kingdom, and Brazil, which accounted for $53 \%$ of the total number of nationalities represented in the research papers addressing $\mathrm{CE}$ and I4.0 topics. The second group of 17 countries represents $47 \%$, from which China, France, and South Africa stand out. 
Table 5. Contributions per country.

\begin{tabular}{cccccc}
\hline Country & No. & \% & Country & No. & \% \\
\hline Italy & 7 & 16.67 & Bulgaria & 1 & 2.38 \\
\hline India & 6 & 14.29 & Canada & 1 & 2.38 \\
\hline Spain & 6 & 14.29 & Czech Republic & 1 & 2.38 \\
\hline United Kingdom & 5 & 11.90 & Denmark & 1 & 2.38 \\
\hline Brazil & 4 & 9.52 & Germany & 1 & 2.38 \\
\hline China & 3 & 7.14 & Ireland & 1 & 2.38 \\
\hline France & 3 & 7.14 & Lithuania & 1 & 2.38 \\
\hline South Africa & 3 & 7.14 & New Zealand & 1 & 2.38 \\
\hline United States & 2 & 4.76 & Poland & 1 & 2.38 \\
\hline Norway & 2 & 4.76 & Singapore & 1 & 2.38 \\
\hline Austria & 1 & 2.38 & Ukraine & 1 & 2.38 \\
\hline
\end{tabular}

\section{Discussion}

Based on the papers reviewed, the authors are in agreement that CE and I4.0 exhibit correlated behavior since they depend on each other to achieve the transition from a linear to circular model to guarantee sustainability in supply chains. In our review, we found very few studies that address the impact of CE in society, as well as the mechanisms used to measure the effects that CE implementation generates in people. In fact, only three studies came close. The first one used ideas derived from CE principles to promote a collaborative supply chain model for the healthcare sector, engaging people and society to change the focus from consumer to co-creator due to the crisis generated by COVID-19 [40].

In the second study, Cosimato et al. [41] claimed that individual, community, or global happiness can be approached as a key component for circular logic-based sustainable development. To support this theoretical research, these authors proposed an extreme case study, highlighting the way in which a specific Italian prison community approached the individual and collective aspects of happiness, both in the present and in the future. Finally, the third study examined the possible relationships between age and awareness of the Industry 4.0 concept, considering the fundamental skills and capacities requiring the use of new technologies and the expectation of future technological changes as threats [8].

In order to measure the maturity level of industry 3.0, and to migrate to industry 4.0 based on circular economy, it is important to consider the following elements: decentralization, interoperability, ability to adapt to changes, real-time working capabilities, virtualization, and service orientation [6,35].

\section{Future Work}

In this review, we established a relationship between $\mathrm{CE}$ and other areas of study, such as SCM, TD, MAN, BM, SUS, and PS, in the last three years. These relationships must be further studied in greater depth using different methodologies. To this end, this work updates the state-of-the-art for future research and offers concrete information on the research advances regarding $C E$ and its impact in areas other than those that have been recently documented in published works.

For future research, we recommend emphasizing the strategies and the social and individual dynamics implemented in different countries in terms of their economic development, so that the impact from I4.0 technologies and the transition toward sustainability is easier to assimilate and incorporate into daily life, thus allowing processes that develop in harmony with the environment and the protection of the planet. 


\section{Conclusions}

This literature review allowed us to identify the different theories and concepts revolving around CE and I4.0 through a comprehensive work of understanding, analysis, and synthesis. Several of the papers reviewed provided arguments from case studies based on industrial or organizational processes. Other papers focused on literature reviews to find methodologies and arguments that supported other hypotheses.

This research identified relationships and concordances in the studies reviewed; however, there are still areas of research in which the implementation of CE principles through I4.0 in the organizational value chains is not evidenced. It is important to mention that very few studies addressed the impacts from a transition to CE supported by I4.0 on individuals and society. Although it is true that $\mathrm{CE}$ is based on eco-conceptions, industrial and territorial ecology, functional economy, second use, reuse, repair, recycling, and valuation, we still lack studies that show that these pillars positively benefit individuals by guaranteeing sustainability or the development of sustainable life from a social and political perspective.

According to the works reviewed, it is still uncertain how much the transition to the CE may cost society and what strategies these actors have available to avoid social failure. In emerging economy countries, adopting the different I4.0 technologies may involve major challenges, in addition to those related to the dynamics required by the system. Here, we show that it is feasible to build an intelligent industry (I4.0) based on a CE model. The disruptive technologies that are the basis of I 4.0 will be managed as active elements for a circular economy business model and, in turn, achieve the 17 targets set by the OECD for 2030. In I4.0, the CE model allows for measuring the income generated by chain production waste in a way that can increase the ROI while decreasing the impact on the environment.

Author Contributions: Project administration, Funding acquisition and Writing-review \& editing, C.A.T.R.; Investigation and Writing-original draft, D.F.C.; Resources and Methodology, J.H.O. and O.I.K.; Validation and Supervision, M.A.V. All authors have read and agreed to the published version of the manuscript.

Funding: This research has been funded by Dirección General de Investigaciones of Universidad Santiago de Cali under call No. 01-2021.

Institutional Review Board Statement: Not applicable.

Informed Consent Statement: Not applicable.

Data Availability Statement: The data that support the findings of this study are available from the corresponding author upon reasonable request.

Conflicts of Interest: The authors declare that they have no conflicts of interest to report regarding the present study.

\section{References}

1. Belaud, J.-P.; Prioux, N.; Vialle, C.; Sablayrolles, C. Big data for agri-food 4.0: Application to sustainability management for by-products supply chain. Comput. Ind. 2019, 111, 41-50. [CrossRef]

2. Rosa, P.; Sassanelli, C.; Urbinati, A.; Chiaroni, D.; Terzi, S. Assessing relations between Circular Economy and Industry 4.0: A systematic literature review. Int. J. Prod. Res. 2019, 58, 1662-1687. [CrossRef]

3. Asiimwe, M.M.; Kock, I.H. An analysis of the extent to which industry 4.0 has been considered in sustainability or socio-technical transitions. S. Afr. J. Ind. Eng. 2019, 30, 41-51. [CrossRef]

4. Tombido, L.L.; Louw, L.; Van Eeden, J. A systematic review of 3pls' entry into reverse logistics. S. Afr. J. Ind. Eng. 2018, 29, 235-260. [CrossRef]

5. Rajput, S.; Singh, S.P. Connecting circular economy and industry 4.0. Int. J. Inf. Manag. 2019, 49, 98-113. [CrossRef]

6. Yadav, G.; Luthra, S.; Jakhar, S.K.; Mangla, S.K.; Rai, D.P. A framework to overcome sustainable supply chain challenges through solution measures of industry 4.0 and circular economy: An automotive case. J. Clean. Prod. 2020, 254, 120112. [CrossRef]

7. Gómez, A.M.; González, F.A.; Luque, A. A holonic framework for managing the sustainable supply chain in emerging economies with smart connected metabolism. Resource. Conserv. Recycl. 2018, 141, 219-232. [CrossRef]

8. Kuba, F.M. Industry 4.0 and its impact on employees' age. Littera Scr. 2019, 12, 1-12.

9. Bressanelli, G.; Adrodegari, F.; Perona, M.; Saccani, N. Exploring How Usage-Focused Business Models Enable Circular Economy through Digital Technologies. Sustainability 2018, 10, 639. [CrossRef] 
10. de Sousa, A.B.L.; Chiappetta, C.J.; Filho, M.G.; Roubaud, D. Industry 4.0 and the circular economy: A proposed research agenda and original roadmap for sustainable operations. Springer Sci. 2018, 270, 273-286.

11. Rocca, R.; Rosa, P.; Sassanelli, C.; Fumagalli, L.; Terzi, S. Integrating Virtual Reality and Digital Twin in Circular Economy Practices: A Laboratory Application Case. Sustainability 2020, 12, 2286. [CrossRef]

12. García, A.; González, F.A.; Roldán, A.C. Propuesta de marco de trabajo para la evaluación de la sostenibilidad de productos desde el paradigma de la economía circular basada en industria 4.0 (parte 1). Cod. 8631, Ingeniería y tecnología del medio ambiente. Rev. DYNA 2018. [CrossRef]

13. Nascimento, D.L.M.; Alencastro, V.; Quelhas, O.L.G.; Caiado, R.G.G.; Garza-Reyes, J.A.; Rocha-Lona, L.; Tortorella, G. Exploring Industry 4.0 technologies to enable circular economy practices in a manufacturing context: A business model proposa. J. Manuf. Technol. Manag. 2019, 30, 607-627. [CrossRef]

14. Snyder, H. Literature review as a research methodology: An overview and guidelines. J. Bus. Res. 2019, 104, 333-339. [CrossRef]

15. Singh, S.P.; Singh, R.K.; Gunasekaran, A.; Ghadimi, P. Supply Chain Management, Industry 4.0, and the Circular Economy. Resour. Conserv. Recycl. 2018, 142, 281-282.

16. Manavalan, E.; Jayakrishna, K. An Analysis on Sustainable Supply Chain for Circular Economy. Procedia Manuf. 2019, 33, 477-484. [CrossRef]

17. Daú, G.; Scavarda, A.; Scavarda, L.F.; Portugal, V.J.T. The Healthcare Sustainable Supply Chain 4.0: The Circular Economy Transition Conceptual Framework with the Corporate Social Responsibility Mirror. Sustainablity 2019, 11, 3259. [CrossRef]

18. Dev, N.K.; Shankar, R.; Qaiser, F.H. Industry 4.0 and circular economy: Operational excellence for sustainable reverse supply chain performance. Resour. Conserv. Recycl. 2020, 153, 104583. [CrossRef]

19. Okorie, O.; Salonitis, K.; Charnley, F.; Moreno, M.; Turner, C.; Tiwari, A. Digitisation and the Circular Economy: A Review of Current Research and Future Trends. Energies 2018, 11, 3009. [CrossRef]

20. Mortensen, S.T.; Nygaard, K.K.; Madsen, O. Outline of an Industry 4.0 Awareness Game. Procedia Manuf. 2019, 31, 309-315. [CrossRef]

21. Sarc, R.; Curtis, A.; Kandlbauer, L.; Khodier, K.; Lorber, K.; Pomberger, R. Digitalisation and intelligent robotics in value chain of circular economy oriented waste management-A review. Waste Manag. 2019, 95, 476-492. [CrossRef] [PubMed]

22. Limba, T.; Novikovas, A.; Stankevičius, A.; Andrulevičius, A.; Tvaronavičienè, M. Big Data Manifestation in Municipal Waste Management and Cryptocurrency Sectors: Positive and Negative Implementation Factors. Sustainability 2020, 12, 2862. [CrossRef]

23. Lin, K.-Y. User experience-based product design for smart production to empower industry 4.0 in the glass recycling circular economy. Comput. Ind. Eng. 2018, 125, 729-738. [CrossRef]

24. Garcia, F.E.; González, R.; Ferrari, A.M.; Volpi, L.; Pini, M.; Siligardi, C.; Settembre, D. Identifying the Equilibrium Point between Sustainability Goals and Circular Economy Practices in an Industry 4.0 Manufacturing Context Using Eco-Design. Soc. Sci. 2019, 8, 241. [CrossRef]

25. Kerdlap, P.; Choong, J.S.; Ramakrishna, S. Zero waste manufacturing: A framework and review of technology, research, and implementation barriers for enabling a circular economy transition in Singapore. Resources. Conserv. Recycl. 2019, 151, 104438. [CrossRef]

26. Palka, D. Closed circuit economy in the context of implementing new technologies. In Proceedings of the 19th International Multidisciplinary Scientific GeoConference SGEM, Albena, Bulgaria, 28 June-7 July 2019.

27. Sterev, N. New industrial business models: From linear to circular economy approach. Trakia J. Sci. 2019, 17, 511-523. [CrossRef]

28. Bag, S.; Wood, L.C.; Mangla, S.K.; Luthra, S. Procurement 4.0 and its implications on business process performance in a circular economy. Resour. Conserv. Recycl. 2020, 152, 104502. [CrossRef]

29. Jabbour, C.J.C.; Fiorini, P.D.C.; Wong, C.W.; Jugend, D.; Jabbour, A.B.L.D.S.; Seles, B.M.R.P.; Pinheiro, M.A.P.; da Silva, H.M.R. First-mover firms in the transition towards the sharing economy in metallic natural resource-intensive industries: Implications for the circular economy and emerging industry 4.0 technologies. Resour. Policy 2020, 66, 101596. [CrossRef]

30. Tseng, M.-L.; Tan, R.R.; Chiu, A.S.; Chien, C.-F.; Kuo, T.C. Circular economy meets industry 4.0: Can big data drive industrial symbiosis? Resour. Conserv. Recycl. 2018, 131, 146-147. [CrossRef]

31. García, A.; González, F.A.; Roldán, A.C. Propuesta de marco de trabajo para la evaluación de la sostenibilidad de productos desde el paradigma de la economía circular basada en industria 4.0 (parte 2). Cod. 8718, Ingeniería y tecnología del medio ambiente. Rev. DYNA 2018. [CrossRef]

32. Forlastro, G.; Chiesa, I.; Gena, C.; Cietto, V. IoT for the Circular Economy: The case of a mobile set for video-makers. In Proceedings of the MobileHCI'18: 20th International Conference on Human-Computer Interaction with Mobile Devices and Services Adjunct, Barcelona, Spain, 3-6 September 2018.

33. Garcia-Muiña, F.E.; González-Sánchez, R.; Ferrari, A.M.; Settembre-Blundo, D. The Paradigms of Industry 4.0 and Circular Economy as Enabling Drivers for the Competitiveness of Businesses and Territories: The Case of an Italian Ceramic Tiles Manufacturing Company. Soc. Sci. 2018, 7, 255. [CrossRef]

34. Sedikova, I. Development of conceptual principles of the circular economy. Food Ind. Econ. 2019, 11. [CrossRef]

35. Gribaudo, M.; Manini, D.; Pironti, M.; Pisano, P. Circular Economy: A Performance Evaluation Perspective. In Proceedings of the VALUETOOLS'20: 13th EAI International Conference on Performance Evaluation Methodologies and Tools, Tsukuba, Japan, 18-20 May 2020.

36. Kerin, M.; Pham, D.T. A review of emerging industry 4.0 technologies in remanufacturing. J. Clean. Prod. 2019, 237, 237. [CrossRef] 
37. Koilo, V. Evidence of the Environmental Kuznets Curve: Unleashing the Opportunity of Industry 4.0 in Emerging Economies. J. Risk Financ. Manag. 2019, 12, 122. [CrossRef]

38. Turner, C.J.; Moreno, M.; Mondini, L.; Salonitis, K.; Charnley, F.; Tiwari, A.; Hutabarat, W. Sustainable production in a Circular Economy: A business model for re-distributed manufacturing. Sustainability 2019, 11, 4291. [CrossRef]

39. Birkel, H.S.; Veile, J.W.; Müller, J.M.; Hartmann, E.; Voigt, K.-I. Development of a Risk Framework for Industry 4.0 in the Context of Sustainability for Established Manufacturers. Sustainability 2019, 11, 384. [CrossRef]

40. Wuyts, W.; Marin, J.; Brusselaers, J.; Vrancken, K. Circular economy as a COVID-19 cure? Resour. Conserv. Recycl. 2020, 162, 105016. [CrossRef]

41. Cosimato, S.; Faggani, M.; Prete, M. The co-creation of value for pursuing a sustainable happiness: The analysis of an Italian prison community. Socio-Econ. Plan. Sci. 2020. [CrossRef] 